\title{
Introduction: The Americanization of John Dos Passos
}

When John Dos Passos criticized the New Masses in 1926 because its editors were too little interested in "exploring America," ${ }^{1}$ he was in effect charting much of his own future. In most of his half century of writing, Dos Passos consistently tried to image-and thereby define-the character of the United States and its people. Unchastened by the enormity of his task, he wrote book after book in search of the national identity and its embodiment in a convincing American hero, beginning with Manhattan Transfer, the 1925 portrait of New York, and ending with the posthumously published Century's $E b b$ in 1975. For him, this literary exploration of America became "a prospecting trip, drilling in unexpected places, following unsuspected veins, bringing home specimens as yet unclassified."

Enthusiastic as Dos Passos was about being the "chronicler" of American life, his early writing revealed little of that eventual interest. Nearly all his stories published in The Harvard Monthly had foreign settings, as did his poems and his first two published novels, One Man's Initiation: 1917 and Three Soldiers (the novels, ostensibly, because they were about World War I). During his college and war years, travel was both Dos Passos' avocation and his love, and the writing he did from I9I2 through the next decade reflects his fascination with foreign cultures. As early as I9I8, however, he wrote of America with real affection and humor; and in 1920, for the first time since his Harvard days, he spent most of the summer in New York, a city that both "amused and appalled him." ${ }^{3}$ In subsequent years of traveling, through both Europe and Asia Minor, Dos Passos' travel writing reflected his quandary: America, even with its scarcity of literary and cultural traditions, was exciting in its very naivete. While in some respects it could not compare with older cultures, in others it surpassed them. Dos Passos said in I919, 
"I admit that America is more dear to me than Europe-probably its colossal hideousness, its febrile insanity are evolving towards a better life for man" ${ }_{i}{ }^{4}$ and in ${ }_{1}$ 920, writing from London, he echoed the sentiment: "America has an unhallowed attraction for me." 5 Then in 1922 came the first of his antitravel comments:

At present I am bound for the U.S.A. having, bi Jasus, destroyed the illusion of geography-No more retchings after Cook's tours, or pinings to join the agile Mr. Neuman-in his Travel Talks-All of it is bunk. ... There's as bad wine to be drunk in Tiflis as on Eleventh Street, the phonographs squawk as loud in Baghdad as they do in Sioux City, and politics are no more comic in Teheran than in Washington D.C. ${ }^{6}$

Dos Passos may have been gravitating toward an allegiance to "home," even in the midst of the expatriate culture many young American liberals had created abroad, but his writing had yet to illustrate that interest. His impressionistic war novels and 1923 Streets of Night were too obviously romantic to signal the innovation in approach and in theme that he felt a truly American literature demanded. He had written in his 1916 essay "Against American Literature" that too little American writing was native, that most of it was "foreign-inspired." American writers had yet to write about their primary themes and interests; neither had they yet presented any concept of what he called the American "national soul" (âme nationale). So unlike the passionless formality of the English, the American soul to Dos Passos was instead a "genial, ineffectual, blindly energetic affair." (He says this with the mild humor that came to mark most of his comments about the American character: even in his later somewhat more critical writing his anger was usually directed toward institutions and their abuses, seldom toward the American people per se.)

He complained that the American novel lacked "color and passion"; "Our books are like our cities; they are all the same." And he described that sameness as being "sincere, careful, and full of shrewd observation of contemporary life," using the novels of Edith Wharton and Robert Herrick as illustrations. Instead of these novels of manners, Dos Passos asked for novels of passion, filled with what he then called "earth-feeling." In short, he said, "The tone of the higher sort of writing in this country is undoubtedly that of a well brought up and intelligent woman, tolerant, versed in the things of this world, quietly humorous, but bound, tightly, in the fetters of 
'niceness,' of the middle-class outlook." He objected as well to the methods of these novelists, criticizing them for relying on abstractions instead of using concrete images and representations of "human qualities." Little matter, said Dos Passos, that America had few folk traditions and a scant mystic and primitive heritage; by using what did exist, writers could infuse their work with power, as had Walt Whitman, the man Dos Passos considered America's only great poet.

The essay ends with the statement of the attitude that would pervade Dos Passos' writing for the next fifty years (an attitude remarkable for its consistency, if not for its perspicacity), that America and its literature had the potential for great fruition yet that, because of continual misdirection, its promise might remain only promise. Instead of becoming the home of great literature, America might rather become "the Sicily of the modern world," producing only "steel and oil and grain."7

Hardly definitive so far as the subject of American literature is concerned, this first (commercially) published essay ${ }^{8}$ does indicate Dos Passos' major personal interests as writer-a deep involvement with American culture and the literature it might be expected to produce (here as yet undefined, except for his emphasis on Whitmanic subjects); a consistent interest in the artistic methods that would make such literature possible, especially in characterization; and a fascination with what he saw as the American character ("genial, ineffectual, blindly energetic"). The latter sometimes came surprisingly close to being his own character. The blurring between the observable persona of imaginative fiction and a revealing selfportrait was one of the most interesting of the changes in Dos Passos' half century of fiction. An autobiographical persona dominated both his early and his very late fiction: in the early, Martin Howe and John Andrews, impassioned if iconoclastic, and in the late, Ro Lancaster and Jay Pignatelli, authoritative yet bewildered. ${ }^{9}$ As this study will show, the Dos Passos persona appears in each novel but often as only a minor character and seldom as an authorial voice. Not until The Great Days, Midcentury, and Century's Ebb did Dos Passos use a clearly recognizable self as protagonist. Though not unique, this pattern does show the comparative restraint that marked Dos Passos' writing. Convinced that objectivity was desirable, he tried to create distance between persona and self by turning from the single protagonist of One Man's Initiation: 1917 to the multiple protagonists of Three Soldiers and then to the antiprotag- 


\section{xvi Introduction}

onists of Manhattan Transfer and U.S.A. The effectiveness of his presentation, which was sometimes satiric, depended in part on the reader's concept of hero and in part on some knowledge of American "success" myths, because Dos Passos often played his characters against those expectations. His truly successful protagonists seldom conform to society's ideas of achievement.

Dos Passos' methods of presenting character were not those of the intensive psychological study; instead he used the panoramic or at least multiple, and often external, view. Because his method was so different from the more familiar modernist approach of, say, Conrad or Faulkner, for example, some readers thought him relatively disinterested in character, and it was a commonplace that Dos Passos was more sociological than psychological in his emphasis. Dos Passos himself contributed to this evaluation, especially during the I930s, when he emphasized that his apprehension of America as country was his first purpose in writing, feeling as he did that the novelist's job was "to capture the snarl of the human currents of his time, so that there results an accurate permanent record of a phase of history." ${ }^{10}$ Avidly interested in social and economic developments, Dos Passos thought that understanding such developments was crucial to the modern writer: "The writer has got to put his mind on the world around him. He has got to understand-I do not mean complain about, I mean understand-the industrial set-up that is so ruthlessly changing the basis of society. . . . His business is to justify the ways of machinery to man."11

Countless notes and notebooks among Dos Passos' papers attest that he worked hard to understand the vicissitudes of the financial/ industrial complex that America had become. Such an interest led to the subject matter of his later fiction-the taxicab war and labor union power structure in Century's Ebb and Midcentury; Washington bureaucracy in the District of Columbia trilogy; the dynamics of the film industry in Most Likely To Succeed. But his concern with economics was always subordinate to his larger purpose of describing the interaction among people: Dos Passos considered his primary role to be an observer of American morality. He felt constrained to protest, both in writing and in person, when justice was abused; thus he played active roles in the Sacco-Vanzetti protests, the Harlan County, Kentucky, mine activities, the Spanish Civil War, World Wars I and II, etc. As Alfred Kazin described Dos Passos' commitment, he had a genuine "passion for history, for retracing history's creative moments": "Alone among his literary cronies, Dos 
Passos managed to add this idea of history as the great operative force to their enthusiasm for radical technique, the language of Joyce, and 'the religion of the word."'12 Harry T. Moore described him, similarly, as "the only major American novelist of the twentieth century who has had the desire and the power to surround the lives of his characters with what Lionel Trilling once called 'the buzz of history.' . . . He has given us an image of a major aspect of our experience that has hardly been touched by any other novelist of our time."13 And Joseph Epstein concluded in a I976 essay, "This joining of the artistic to the political is one of the things that made the early Dos Passos so appealing a figure. Along with being the most educated of the writers of the I 920 's, he was also the most engagé."14

To the charge, often heard, that Dos Passos' political attitudes were inconsistent, one might answer that various shifts in the economic world made certain continuing stances impractical. In the I 920 and I930s, for example, labor unions seemed to offer help to undervalued American workers. By the I950s, however, corruption within most union leadership was depriving the workers of what little power they had won. Labor unions, for Dos Passos, changed from promising to threatening-less because of his personal politics than because of the composition of those bodies. As he explained in The Best Times, "When the meaning of political slogans turns topsyturvy every few years, anyone who tries to keep a questioning mind ... has to put up with having old friends turn into unfriends and even into enemies." ${ }^{15} \mathrm{He}$ had summarized as early as I939, "My sympathies, for some reason, lie with the private in the front line against the brass hat; with the hodcarrier against the strawboss ...; with the laboratory worker against the stuffed shirt in a mortarboard; with the criminal against the cop."16 For Dos Passos, the continuing struggle was that between the individual and an organized social, political, or financial structure. "The theme is freedom," he repeated often, coupled with his definition, "Individuality is freedom lived."17

It could also be said that differences in the critical estimation of Dos Passos' work were due not to his choice of subject or method so much as to the highly volatile intellectual temper of the r 920 s and I930s. Contrary to the generalizations of some critics, the only striking "change" in Dos Passos' writing occurred early and separated his first three novels, travel writing, and poems (work dominated by the themes of the lost son, the effete young man so far re- 
moved from life that he cannot find any place within it, reverence for and distance from women, and cultural and familial rootlessness) from the 1925 Manhattan Transfer, his first obvious use of the "exploration-of-America" theme. In one sense, after Dos Passos left off using clearly autobiographical subjects-at least so obviously-he seemed to begin thinking of himself as an American instead of some advantaged young wanderer. Part of his interest in the workingclass character lay in that person's distance from his own situation; part stemmed from his war experiences, when he had learned to know a range of people and had developed a sense of "kinship with individual men and women."18 Influenced further by the social unrest of the late I920s, much of which surrounded the Sacco-Vanzetti protests, Dos Passos' fascination with labor and seemingly leftist characters coincided with the proletarian movement of the I930s; therefore, and partly by accident, he became known as a "proletarian" novelist.

As Dos Passos said reluctantly, "There was a short period during which I actually believed that if you put underdog in Topdog's place he'd behave better. This was a very serious fallacy that made useless most of the thinking that stemmed from it."19 When his romance with the working-class character ended, Marxist critics insisted that Dos Passos had changed political positions. A reading of his fiction, however, shows very little shift in attitude. While at one point he had looked to communism with hope, he remained skeptical, even during his Russian visit, and later, with the formation of New Masses, controversy between Dos Passos and the other contributors was evident from the beginning, as in his essay "The New Masses I'd Like." As Granville Hicks summarized in 1950,

Nothing is deeper in the man than his fear of power. To begin with, he feared the power of the military, as he had experienced it in the first World War, and the power of men of wealth. The hatred of war and exploitation grew so acute that he accepted for a time the tempting radical doctrine that only power can destroy power. But what he saw of communism in Russia, in Spain, and at home convinced him that the destroying power could be more dangerous than the power it overcame. The New Deal, whatever its accomplishments, represented a great concentration of power, and he must always have been uneasy about it. As for war, Dos Passos hated it in and for itself and because it inevitably resulted in the piling of power upon power. ${ }^{20}$ 
By the time Adventures of a Young Man, a vehement exposé of communist sympathizers, was published in 1939, there was no way to pretend that Dos Passos was anything other than anti-Communist. The subsequent District of Columbia and the other late novels only reinforced his anti-Red and antipower position.

The undeniable sense of history in most of Dos Passos' writing is the bridge between his best-known work and the later history and fiction. Materials used in I919, the second book of the U.S.A. trilogy, which deals directly with World War I and its aftermath, and in Mr. Wilson's War, the historical treatment of the same period, are frequently similar and might also have appeared in One Man's Initiation and Three Soldiers. In addition to factual information, the books contain scenes, characters, and incidents that shape the larger attitudes of the reader. Dos Passos' imagistic method gives specific scenes a vividness that makes them memorable: the soldier whose girl surprises him with a large box of candy; the shelled waste of a cathedral; the distraught soldier who kills his hated lieutenant -for Dos Passos, material evoked method. The visual, direct presentation caught the real events-or the apparently real events-that sparked his primary interest. As he recalled in I968, "I was thoroughly embarked on an effort to keep up a contemporary commentary on history's changes." 21

Artist that he was, however, Dos Passos knew that his observations would be believed only if his techniques succeeded. The difference between his successful novels and those that seemed weak diatribes was often a difference of method. Characteristically, whether his writing was in fiction or history, the concrete scene, the specific detail, serves to suggest a philosophical attitude or situation. Whether one calls this attention to the concrete "imagism" (as the poets did), "expressionism" (the term in drama), "impressionism" (the fictional term, more appropriate to Dos Passos' first novels than to the mature work), or the "Camera Eye" (as he himself had labeled part of his method in U.S.A), method dominates his writing throughout his career. Given as he was to imaging his characters, his reliance on devices like those used in early films -juxtaposition resembling collage with its shifting content and point of view; emphasis on speed; noninterference by an authorial conscience-seems reasonable. Dos Passos' aim was, newsreellike, to present, to bombard, the viewer-reader with a spectrum of scenes and images, from which some sense of the real "history" being lived - whether personal or social-could accumulate. He recalled that his aim was "simultaneity": 
Direct snapshots of life. Reportage was a great slogan. The artist must record the fleeting world the way the motion picture film recorded it. By contrast, juxtaposition, montage he could build drama into his narrative. Somewhere along the way I had been impressed by Eisenstein's motion pictures, by his version of old D. W. Griffith's techniques. Montage was his key word. ${ }^{22}$

An important corollary to this method was the idea of "reportage" (later, rapportage in Dos Passos' vocabulary), the assumed objectivity of the viewer-author. Part of the difficulty with reading Manhattan Transfer and U.S.A. is that there is no announced authorial perspective. Characters and events are literally presented without directional language or situation: we are not sure, until we know something of Dos Passos' narrative contexts, whether to criticize or to applaud Daughter's love for Richard Savage or J. Ward Moorehouse's ambition. Dos Passos considered his fiction during these years to be neither completely impartial nor charged in the sense of the nineteenth-century novel. As he recalled later, "Artistic works to be of lasting value must be both engaged and disengaged. They must have a certain life, a certain aloofness that separates them from the obsessions of the hour. At the same time they must encompass . . the whole range of the human spirit." ${ }^{\prime 23}$

Dos Passos' concept of novels as history, history presented more accurately and more deeply than conventional history-which he came to describe as "contemporary chronicles"-has its inception in his observation that a few great novels were really "chronicle novels" and drew much of their force from their mixture of history with fictional narrative and character. Speaking of Vanity Fair, War and Peace, and La Chartreuse de Parme, he explained that "the story is the skeleton on which some slice of history is brought back to life. Personal adventures illustrate the development of a society. Historical forces take the place of the Olympians of ancient Greek theater." ${ }^{24}$ Plot exists to reveal the actual machinations of history (not life, as the more common literary term "slice-of-life" would suggest); characters and their adventures exist not because they are of interest in themselves but because they illustrate the ways in which society has developed. And at the root of all of a person's troubles lies neither Fate nor gods but "historical forces." Dos Passos' concept of the "chronicle novel" or his own "contemporary chronicles" differed greatly from the standard literary translation of man-universe-power-plot and should be an essential consideration in any attempt to evaluate the success of his own work. 
The application of these ideas to his aims in the U.S.A. trilogy is evident. "The narrative must carry a very large load," he explains, because American life during the present century is versatile, teeming. "Everything must go in. Songs and slogans, political aspirations and prejudices, ideals, hopes, delusions, frauds, crackpot notions out of the daily newspaper." The business of the modern novelist was to present enough valid historical images that the reader could accurately re-create the scene, the time, being presented. The centrality of his approach and method is clear from Dos Passos' observation that "the U.S.A. narratives were never supposed to end. They were followed by other chronicles from other points of view. Intermittently, and always trying to look out from the vantage point of style, to let the matter mould the style, ${ }^{\prime 25}$ the other chronicles kept coming.

His coining the term "contemporary chronicles" to describe his fiction suggests that Dos Passos realized the uniqueness of his work, this vividly imaged picture of America that was meant to be neither judgmental nor moralistic. Whenever he discussed his writing, however, whether midway through his career or toward its end, he seemed apologetic. His lack of any real financial success may have dampened his understanding of the value of his work, but the critic can view the continuum of his writing without the considerations of popular success and financial profit. The question today, critically, should be why Dos Passos' very important role in the development of modern American fiction need be considered with any tinge of apology. One has only to read the more contemporary fiction of writers like Günter Grass, E. L. Doctorow, or Norman Mailer to realize that Dos Passos' influence may be as great as Hemingway's. Jean Paul Sartre called Dos Passos "the greatest writer of our time ${ }^{\prime \prime} ;{ }^{26} \mathrm{D}$. H. Lawrence praised Manhattan Transfer as "the best modern book about New York that I have read."27 Joseph Epstein, in retrospect, calls U.S.A. "the most ambitious single literary work ever undertaken in this country." 28 Thirty years ago, in I947, Joseph Warren Beach saw the danger that Dos Passos' critical reputation might be eclipsed by the popularity of other writers and identified his interest in sociology, instead of psychology, as the quality of his fiction that would prompt that eclipse. In the age of the psychological novel, Dos Passos' emphasis on panorama instead of individual development was a handicap. As Beach pointed out, "The individual interests him, but mainly as a member of the social body." 29

Consistent with this approach is the fact that Dos Passos tried to locate evil in social patterns rather than in individuals or their 


\section{xxii Introduction}

acts (World War I was, finally, not "Mr. Wilson's War," although Dos Passos' fictional treatment of it might have been more interesting had he felt that it were). We are still trained to be characteroriented readers, and Dos Passos' one consistent difference from other writers contemporary with him was his avoidance of the single psychological study in depth. He recognized the greatness in Faulkner's characterizations, ${ }^{30}$ but his own aim-his personal intention in his fiction-was at times directed toward something else, toward "illustrating the development of a society." Again, the breadth of his aim forced him to choose different methods, but the heart of his own work-regardless of his comments about slogans, songs, and headlines-did remain America and its people.

By the time of the I 944 State of the Nation, Dos Passos had fully realized how central people were to his presentation of the âme nationale. As he arranged vignette after vignette, character sketch after character sketch, his implication was clear: the U.S.A. is its people. Farmers, factory workers, schoolteachers, piano players, barbers-identities exist through physical appearance, attitudes, and especially speech-language is usually Dos Passos' most important means of identifying character. People exist, however, as themselves, as individuals; they do not become so changed in Dos Passos' hands that they become "characters." Dos Passos accepts their external reality and shapes his panorama from it; he does not hypothesize or imagine things about these people that as an external observer he could not know.

The late fiction also shows this authorial caution to interpret the people of his imagination. The only characters Dos Passos draws with any psychological depth are those based on people he has known (Katy in Lulie or Hemingway in George Elbert Warner) or those that increasingly come to represent himself-Ro Lancaster and Jay Pignatelli. Most of the changes in method in the late novels come at least partly from his choice of characters who are more than external presentations.

The fact that Dos Passos chose somewhat different goals for his fiction gave him a distinction that time will prove valuable. Perhaps his panoramic vision will provide more insights to future readers than would a concentration on single characters, because through it the reader receives a great sense of the variety, richness, and complexity possible in any national identity, but particularly in the American modern. Dos Passos also consistently captured the motion of America-its energy, its life, the reality of its dealings and its work-as few other writers have ever done. 
The only accurate critical view of Dos Passos in retrospect is that which recognizes his aims as writer and historian and considers those aims with the evident seriousness that shaped his life as writer. Even though he felt a responsibility to portray the realities of his culture, partly so that readers could better understand themselves, Dos Passos was adamant about the writer's necessity to be, first, an artist. Like so many of his contemporaries, Hemingway and Faulkner among them, Dos Passos believed in the religion of literature, the concept of writer as prophet, as seer. As he recalled, "There was, among many of the young people of my generation, a readiness to attempt great things. . . It was up to us to try to describe in colors that would not fade, our America that we loved and hated. . . ."31 As in so many of his remarks about art, America as subject shares his attention equally with his interest in craft.

One of the most accurate descriptions of the way Dos Passos saw his role as writer-as person concerned with this national soul, the craft of writing, and the morality of characters and life-occurs in his 1932 essay "The Workman and His Tools." Here Dos Passos grants that modern American writers write "to convince people of something," but he goes on to stress the joy writers find in the execution of their art: "There is such a thing as writing for writing's sake. A cabinetmaker enjoys whittling a dovetail because he's a cabinetmaker. . .." For Dos Passos, the writer's delight in craft, in words, is more than "self-expression," although it is that also, precisely because the writer's keenest senses are focused outward, to the visible spectrum of life. The most interesting subject, finally, becomes history and the people who-in living-compose it; and his comments here suggest the relation of formal history to the writer's words, the living language with which any writer-but especially the American writer-should be working:

The mind of a generation is its speech. A writer makes aspects of that speech permanent by putting them in print. He whittles at the words and phrases of today and makes forms for the minds of later generations. That's history. A writer who writes straight is an architect of history. ${ }^{32}$

In 1932 Dos Passos' aims ended with the preservation of what he considered history; by I970, the history of the external world had merged with his own. For Dos Passos-no matter what his subject, no matter what his search-his writing became the means to picture, define, and eventually comprehend both the world around him and himself. As American, he was particularly conscious of his need 
xxiv Introduction

for traditions, and his emphasis on history was a means of informing himself about the country that he both admired and satirized. But, in the process of searching for âme nationale, for hero, and for his own definition as writer, Dos Passos came to realize that every strong writer builds his own world, a creation ultimately subjective and personal. 